\title{
Pemanfaatan Social Media Marketing dan Penyusunan Laporan Keuangan Koperasi Kampung Bunga Kayu Cilember Mekar di Desa Cilember - Kabupaten Bogor
}

\author{
Iis Mariam ${ }^{1}$, Nining Latianingsih ${ }^{2}$, Nidia Sofa ${ }^{3}$ Syamsu Rizal ${ }^{4}$, Titik Purwinarti $^{5}$ \\ 1,2,3,4,5 Lecturer Business Administration, State Polytechnic of Jakarta \\ Jl. Prof. Siwabessy, Kampus Baru UI, Depok 16424 \\ iis.mariam@bisnis.pnj.ac.id, nining.latianingsih@bisnis.pnj.ac.id,nidia.sofa@bisnis.pnj.ac.id, \\ syamsurizal@bisnis.pnj.ac.id,titik.purwinarti@bisnis.pnj.ac.id
}

\begin{abstract}
The implementation of the community service held in Cilember village Cisarua - Bogor Regency has been executed for the fourth time since 2016. The community service is a manifestation of the implementation of Higher Education "Tri Dharma" which must be carried out by lecturers and assisted by administrative staff as well as students. The community service was conducted by providing briefing in theories and practices. The purposes of community service were to provide some training on how to implement an online product marketing (social media marketing); to give excellent communication skills and service; and also to create a financial report in conducting business for the Koperasi Kampung Bunga Kayu Cilember Mekar in Cilember village, Bogor Regency. The community service was held on September 18, 2019 organized by the Business Administration Department. Once the activity completed, it was then followed by monitoring the outcome whether it had been implemented according to business procedures. The aims of these community service activities are to provide knowledge for the apparatus of the village and the community through an intensive training on giving excellent services for the customers in business through good communication skills; marketing the products using social media; and preparing a proper financial report for the Koperasi Bunga Kayu Mekar Cilember-Bogor.
\end{abstract}

Keywords: social digital marketing, financial report, communication

\begin{abstract}
Abstrak
Pelaksanaan pengabdian kepada Masyarakat akan diadakan di desa Cilember Cisarua Pemerintah Kabupaten Bogor - Jawa Barat tahun ini merupakan tahun keempat sejak tahun 2016 pertama kali dilaksanakan menginat pengabdian kepada masyarakat merupakan wujud dari pelaksanaan Tri Dharma Perguruan Tinggi yang wajib dilaksanakan oleh dosen dibantu oleh staf administrasi dan mahasiswa. Pengabdian masyarakat akan dilaksanakan dengan pembekalan secara teori dan praktek. Adapun kegiatan pengabdian masyarakat memberikan pelatihan mengenai pemasaran produk dilakukan secara online (social media marketing), menyusun laporan keuangan Koperasi Kampung Bunga Kayu Cilember Mekar di Desa Cilember, Kabupaten Bogor dan komunikasi serta pelayanan prima yang dilakukan aparatur desa. Kegiatan pengabdian ini dilaksanakan pada tanggal 18 September 2019, setelah pelaksanaan pengabdian ini selesai akan dilakukan monitoring terhadap hasil dari kegiatan pengabdian pada masyarakat apakah sudah diimplementasikan sesuai prosedur yang berlaku. Tujuan dari kegiatan pengabdian kepada masyarakat adalah untuk memberikan pengetahuan kepada aparat desa Cilember dan masyarakat/pedagang yang menjadi anggota Koperasi Kampung Bunga Kayu di desa Cilember, kabupaten Bogor agar mengetahui cara memasarkan produknya dengan menggunakan social media marketing, memberikan pelayanan yang prima dengan komunikasi yang baik serta mampu membuat laporan keuangan koperasi dengan benar.
\end{abstract}

Kata kunci: social digital marketing, laporan keuangan, komunikasi

\section{PENDAHULUAN}

Curug Cilember merupakan salah satu tempat yang memiliki potensi wisata alam yang indah yang terletak di Cisarua, Bogor, Jawa Barat. Lokasi 
wisata ini menarik wisatawan baik domestic maupun asing datang ke Cilember, hal ini berdampak pada pengembangan daerah dan pemberdayaan masyarakat desa Cilember. Koperasi Bunga Kayu Cilember Mekar yang didirikan sebagai luaran dari kegiatan program pengabdian pada masyarakat program studi D4 Administrasi Bisnis tahun 2018 terus dilakukan monitoring perkembangan usahanya. Oleh karena itu pengabdian masyarakat tahun 2019 dilakukan di Cilember-Bogor. Adapun tujuan dari pengabdian pada masyarakat ini adalah memberikan pelatihan, yaitu: (1) cara memasarkan produk hasil UKM bunga kayu di koperasi Bunga Kayu Mekar Cilember secara online, (2) cara komunikasi dan pelayanan prima bagi aparat desa, dan (3) penyusunan format laporan keuangan UKM di koperasi Kampung Bunga Kayu Cilember Mekar.

Pengertian digital marketing menggunakan perkembangan dunia digital untuk melakukan periklanan yang tidak digembar-gemborkan secara langsung akan tetapi memiliki efek yang sangat berpengaruh. Digital marketing adalah segala upaya untuk melakukan pemasaran suatu produk dan jasa melalui media internet [1], [2], [3]. Pemasaran dalam internet marketing bukan hanya untuk meningkatkan penjualan, tapi juga termasuk promosi produk dan jasa baru, branding, dan membina hubungan dengan pelanggan [4],[5],[6],[7].

Definisi koperasi menurut UU Nomor 25 Tahun 1992 bahwa koperasi adalah badan usaha yang beranggotakan seorang atau badan hukum koperasi dengan melandaskan prinsip prinsip koperasi sekaligus sebagai gerakan ekonomi rakyat yang berdasarkan atas azas kekeluargaan.

Laporan keuangan adalah ringkasan dari suatu proses pencatatan (a summary of a recording process) dan transaksi-transaksi keuangan (and financial transactions) yang terjadi selama satu tahun buku yang bersangkutan (that occur during a given fiscal year). Manfaat serta luaran yang dihasilkan dari pengabdian pada masyarakat ini adalah anggota koperasi Bunga Kayu Cilember Mekar di Cilember-Bogor dapat melakuan pemasaran produk bunga kayu menggunakan social digital marketing (instagram, facebook, whatsup), membuat laporan keuangan bisnis sederhana dan praktek berkomunikasi dan pelayanan prima kepada pelanggan dan masyarakat dengan baik.

\section{METODE PELAKSANAAN}

Metode yang digunakan dalam pelaksanaan pengabdian pada masyarakat ini adalah memberikan pelatihan dan pendampingan mengenai social media marketing, praktek komunikasi dan pelayanan prima, serta menyusun laporan keuangan koperasi Kampung BUnga Kayu Mekar Cilember.

Objek yang terlibat dalam pengabdian pada masyarakat ini adalah: (1) Aparat desa Cilember, (2) Pedagang yang tergabung dalam koperasi Kampung Bunga Kayu Cilember Mekar, dan (3) Pemuda serta wakil masyarakat desa Cilember. Teknik pengumpulan data melalui: wawancara dan observasi dengan ketua koperasi dan wakil dari pedagang yang tergabung dalam koperasi Kayu Cilember Mekar desa Cilember, Bogor, Kepala Desa Cilember. Analisis deskriptif digunakan untuk menjelaskan bagaimana proses pelatihan dan pendampingan yang dilakukan oleh tim dari program studi D4 Administrasi Bisnis-PNJ kepada peserta pengabdian pada masyarakat.

Dalam pelatihan ini ada 30 orang peserta yang ikut terdiri dari unsur aparat desa, pemuda dan wakil masyarakat serta anggota koperasi 
Kampung Bunga Kayu Cilember Mekar, Cisarua, Bogor.

\section{HASIL DAN PEMBAHASAN}

Hasil dan pembahasan ditampilkan dalam bentuk uraian deskriptif. Adapun langkah pelaksanaan kegiatan dilakukan sebagai berikut:

Tabel 1. Kegiatan Pengabdian pada Masyarakat Prodi D4 ABT-PNJ 2019

\begin{tabular}{|c|c|c|c|}
\hline$\overline{\mathrm{N}}$ & Tahapan & Kegiatan & Hasil \\
\hline 1 & $\begin{array}{l}\text { Waktu } \\
\text { dan } \\
\text { tempat } \\
\text { kegiatan }\end{array}$ & $\begin{array}{l}\text { Kegiatan } \\
\text { pengabdaian } \\
\text { dilakukan } \\
\text { pada tanggal } \\
18 \\
\text { September } \\
2019 \text {, mulai } \\
\text { pukul 08.30- } \\
16.00 \text { wib } \\
\text { bertempat di } \\
\text { Aula desa } \\
\text { Cilember, } \\
\text { Cisarua, } \\
\text { Bogor, Jawa } \\
\text { Barat }\end{array}$ & $\begin{array}{l}\text { Dilaksanakan } \\
\text { sesuai dengan } \\
\text { jadwal dan } \\
\text { acara dibuka } \\
\text { oleh Pembantu } \\
\text { Direktur II } \\
\text { Bidang } \\
\text { Administrasi } \\
\text { dan Keuangan } \\
\text { PNJ serta dan } \\
\text { Kepala Desa } \\
\text { Cilember. } \\
\text { Hadir juga } \\
\text { undangan } \\
\text { tokoh } \\
\text { masyarakat } \\
\text { desa Cilember } \\
\text { serta peserta } \\
\text { pelatihan dan } \\
\text { dosen program } \\
\text { studi D4 } \\
\text { Administrasi } \\
\text { Bisnis } \\
\text { Terapan-PNJ. }\end{array}$ \\
\hline 2 & $\mathrm{P}$ & $\begin{array}{l}\text { Peserta } \\
\text { berjumlah } \\
30 \text { orang } \\
\text { terdiri dari } \\
\text { anggota } \\
\text { koperasi } \\
\text { Bunga Kayu } \\
\text { Mekar } \\
\text { Cilember } \\
\text { Mekar, } \\
\text { Cisarua, } \\
\text { Bogor dan } \\
\text { aparat desa } \\
\text { Cilember. }\end{array}$ & $\begin{array}{l}\text { Semua peserta, } \\
\text { undangan } \\
\text { hadir tepat } \\
\text { waktu dan } \\
\text { mengikuti } \\
\text { semua } \\
\text { kegiatan dari } \\
\text { awal sampai } \\
\text { akhir. } \\
\text { Peserta: } \\
\text { 30 orang } \\
\text { Dosen:15 orng } \\
\text { Mhsw: } 4 \text { orang }\end{array}$ \\
\hline 3 & $\begin{array}{l}\text { Pemateri } \\
\text { (Instrukt } \\
\text { ur) }\end{array}$ & $\begin{array}{l}\text { a.Dosen prodi } \\
\text { D4 ABT } \\
\text { dengan } \\
\text { kualifikasi } \\
\text { dosen yang } \\
\text { memberikan } \\
\text { materi } \\
\text { memiliki } \\
\end{array}$ & $\begin{array}{l}\text { Proses } \\
\text { pelatihan dan } \\
\text { pembimbingan } \\
\text { dilakukan } \\
\text { menggunakan } \\
\text { komunikasi } \\
\text { dua arah } \\
\text { sehingga tidak }\end{array}$ \\
\hline
\end{tabular}

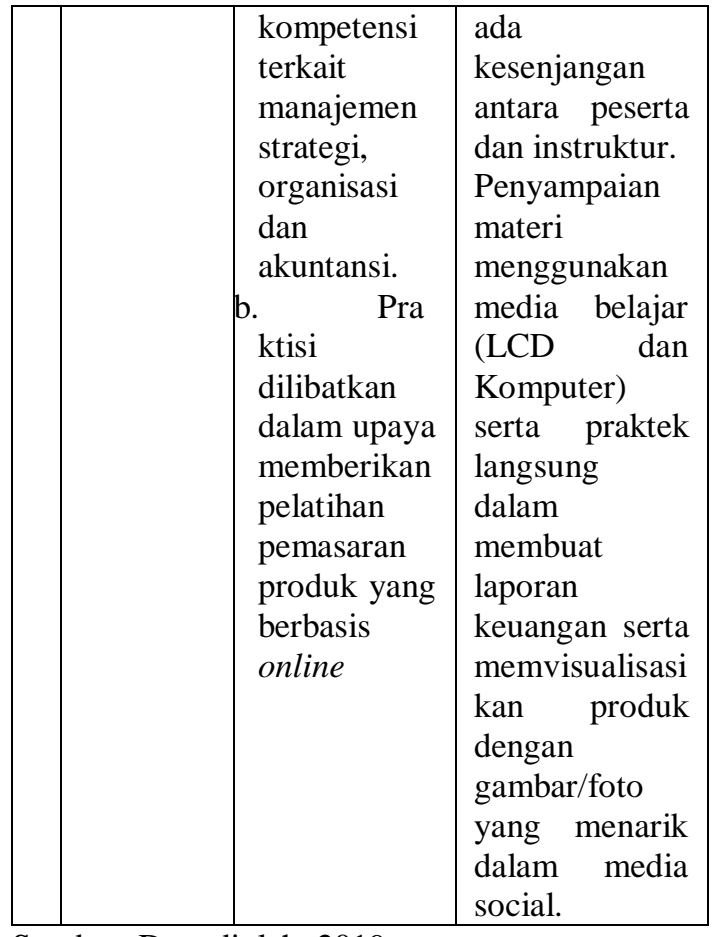

Sumber: Data diolah, 2019

Tabel 2 Materi dan Metode Pelatihan

\begin{tabular}{|c|c|c|}
\hline $\begin{array}{l}\mathrm{N} \\
\mathrm{O}\end{array}$ & MATERI & PELAKSANAAN \\
\hline 1 & $\begin{array}{l}\text { Social Media } \\
\text { Marketing }\end{array}$ & 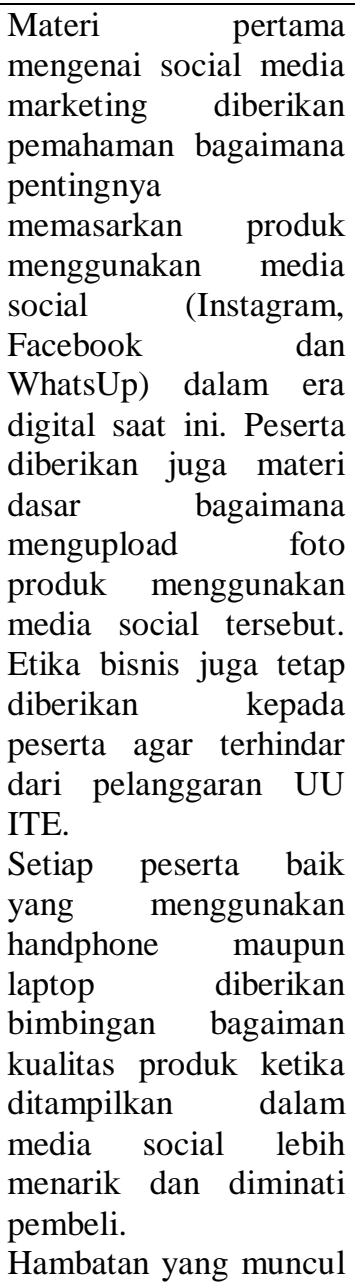 \\
\hline
\end{tabular}




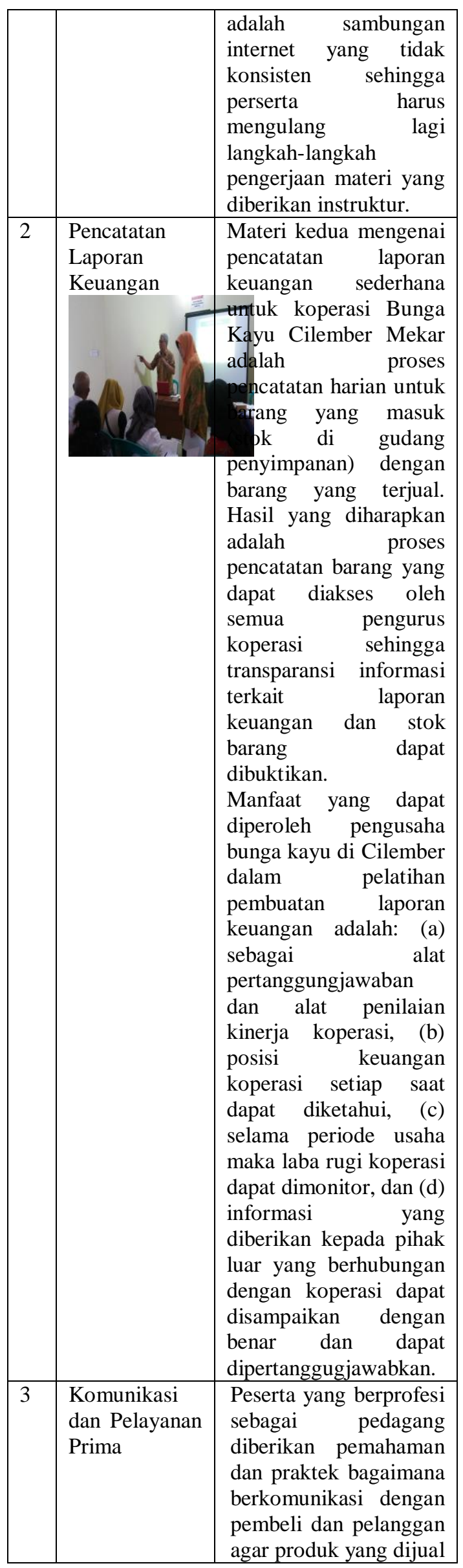

\begin{tabular}{|c|c|c|}
\hline & & 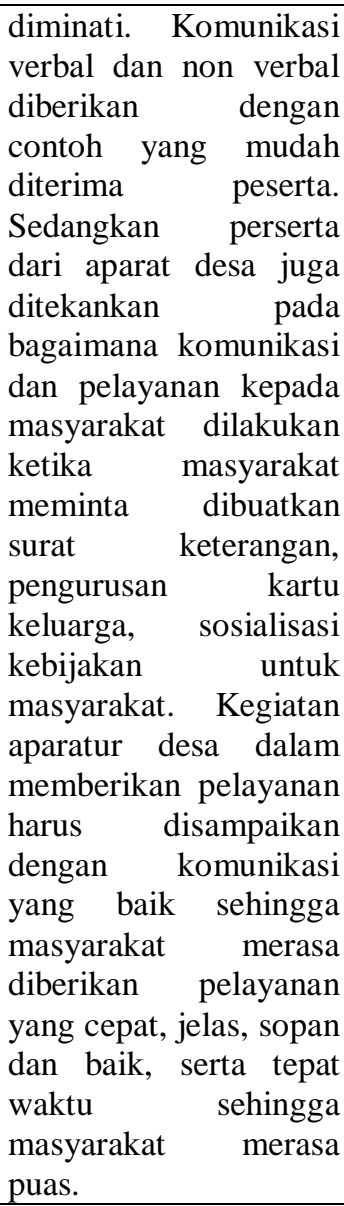 \\
\hline 4 & $\begin{array}{l}\text { Metode } \\
\text { Pelatihan }\end{array}$ & $\begin{array}{l}\text { Ceramah, diskusi, } \\
\text { praktik untuk membuat } \\
\text { gambar produk yang } \\
\text { akan diupload dalam } \\
\text { instagram, facebook, } \\
\text { dan WA, menyusun } \\
\text { pembukuan sederhana } \\
\text { melalui pendekatan } \\
\text { problem based learning } \\
\text { (PBL).serta role play } \\
\text { untuk komunikasi dan } \\
\text { pelayanan prima. } \\
\text { Proses pelatihan } \\
\text { berjalan dinamis } \\
\text { melalui diskusi, role } \\
\text { play, dan tanya jawab } \\
\text { dimana interaksi } \\
\text { pemateri dan peserta } \\
\text { berlangsung dua arah, } \\
\text { dengan menggunakan } \\
\text { metode pembelajaran } \\
\text { PBL sehingga } \\
\text { memudahkan peserta } \\
\text { menerima materi. } \\
\text { Praktik dilakukan } \\
\text { untuk membuat laporan } \\
\text { pembukuan sederhana } \\
\text { dari kegiatan bisnis } \\
\text { yang dilakukan } \\
\text { pengrajin serta }\end{array}$ \\
\hline
\end{tabular}




\begin{tabular}{|l|lr|}
\hline & $\begin{array}{lr}\text { pedagang yang } \\
\text { tergabung dalam } \\
\text { koperasi Bunga Kayu } \\
\text { Cilember Mekar. }\end{array}$ \\
\hline
\end{tabular}

Dalam kegiatan pengabdian pada masyarakat ini juga sekaligus diserahkan bantuan operasional untuk kegiatan koperasi Bunga Kayu Cilember Mekar berupa peralatan ATK untuk mendukung kerja operasional koperasi yang diterima langsung oleh ketua koperasi dan disaksikan oleh kepala desa Cilember, Cisarua, Bogor, Pembantu Direktur II Bidang Administrasi dan Keuangan, Struktural dan dosen jurusan Administrasi NiagaPNJ.

Gambar 3 Penyerahan bantuan untuk Koperasi Bunga Kayu Cilember Mekar

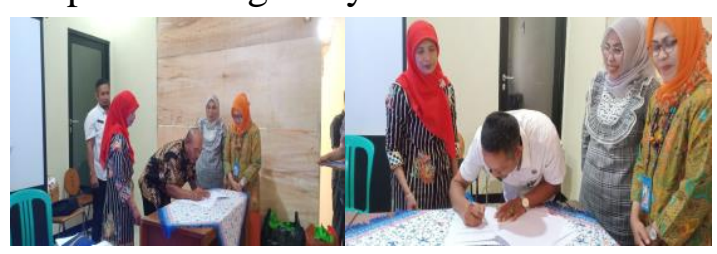

Sumber: Data diolah, 2019

\section{SIMPULAN DAN SARAN}

\section{A. Simpulan:}

1. Potensi bisnis untuk koperasi Bunga Kayu Cilember Mekar memerlukan pendampingan dalam upaya memasarkan produknya melalui media social merujuk pada teori pemasaran jasa dan digital;

2. Kemampuan anggota koperasi Bunga Kayu Cilember Mekar dalam pencatatan penjualan dan keuangan menggunakan laporan keuangan sederhana;

3. Komunikasi dan pelayanan yang diberikan oleh aparat desa Cilember kepada masyarakat menggunakan komunikasi verbal dan non verbal sesuai dengan teori pelayanan prima;

4. Komitmen dan aksi nyata dari pemerintah daerah Bogor, institusi PNJ dan masyarakat pengrajin dan pedagang di desa Cilember, Bogor
Sumber: data diolah, 2019

turut membantu pengembangan koperasi Bunga Kayu Cilember Mekar sehingga tetap bertahan dan mampu berdaya saing dengan usaha sejenis.

\section{B. Saran}

1. Pemerintah desa secara terus menerus memberdayakan masyarakat dalam pengembangan dan pemberdayaan koperasi Bunga Kayu Cilember Mekar

2. Adanya pendampingan tidak hanya dari pemerintah desa tetapi juga dari dinas koperasi dalam meningkatkan usaha koperasi Bunga Kayu Cilember Mekar, Bogor terkait pemasaran, pembukuan dan etika bisnis;

3. Pengurus dan anggota koperasi Bunga Kayu Cilember Mekar, Bogor harus terus berkomitmen memajukan koperasi dan menghindari konflik dalam organisasi;

4. Peran PNJ terus melakukan pendampingan dan monitoring terhadap kegiatan koperasi Bunga Kayu Cilember Mekar sebagai desa binaan yang dijadikan percontohan dalam kegiatan pengabdian pada masyarakat.

\section{UCAPAN TERIMA KASIH}

Penulis mengucapkan terima kasih kepada: (1) P3M-PNJ yang telah mendanai kegiatan pengabdian pada masyarakat, (2) Kepala Desa CilemberBogor yang telah bekerjasama dalam memberikan informasi data dan dukungan terhadap pelaksanaan pengabdian pada masyarakat, dan (3) Pengurus koperasi Bunga Kayu Cilember Mekar yang berkomitmen untuk mengembangkan koperasi sebagai sarana mensejahterakan anggota koperasi dan berkontribusi kepada 
masyarakat untuk berdaya secara ekonomi.

\section{DAFTAR PUSTAKA}

[1] Heidrick and Struggles. 2009. The Adoption of Digital Marketing in Financial. Services Under Crisis.

[2] Rowles, Daniel. (2014). Digital Branding: A Complete Step By Step Guide To Strategy, tactics And Measurement. London: Kogan Page.

[3] Urban, Glen. L. (2004). Digital Marketing Strategy: text and cases. Pearson Education.

[4 ]Barata, Ateb Adya. 2003. Dasardasar pelayanan prima, jakarta: PT Elek Mediakomputindo

[5] Lovelock, Christopher H. dkk. 2011. Pemasaran Jasa Manusia, Teknologi, Strategi. Jilid I, Edisi Ketujuh. Jakarta: Erlangga

[6] Lupiyoadi, Rambat dan A. Hamdani. 2008. Manajemen Pemasaran Jasa. Jakarta: Salemba Empat

[7] Tjiptono, Fandy. 2012. Service Management Mewujudkan Layanan Prima. Yogyakarta: Andi

[8] Yamit, Zulian. 2013. Manajemen Kualitas Produk \& Jasa. Yogyakarta: Ekonisia

[9] Rangkuti, Freddy. 2002. Measuring Customer Statisfaction: PT Gramedia Pustaka Utama, Jakarta

[10] Etzkowitz, Henry \& Leydesdorff, L. (2000). The dynamic of innovation: From national systems and 'mode 2' to a triple helix of university -industry-government relations. Research Policy, 29 (2), 109-123

[11] Undang-Undang Koperasi Nomor 25 Tahun 1992

[12] Renstra, Visi dan Misi Desa Cilember-Bogor, diakses April 2019 